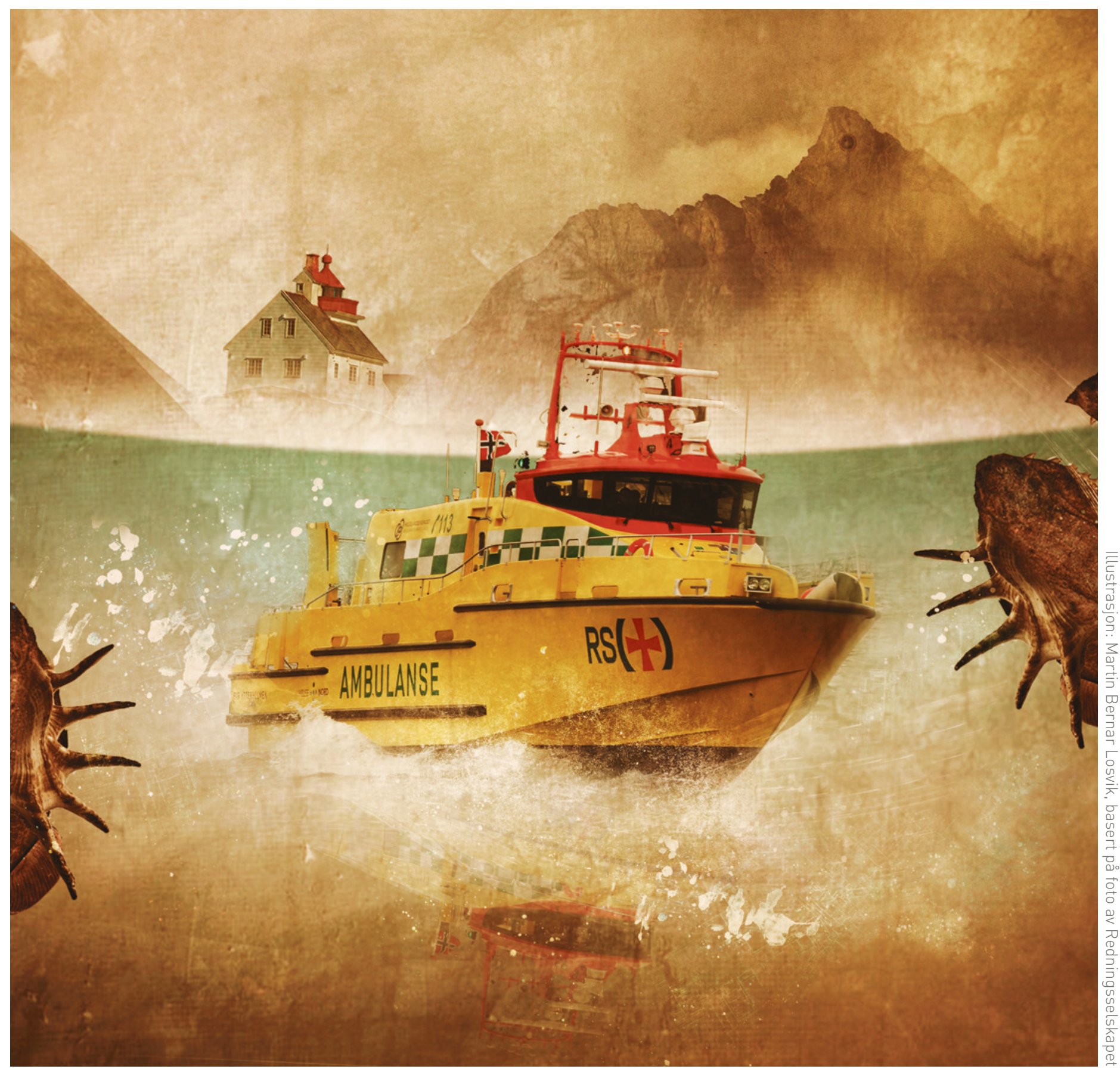

\title{
Ambulansebåten Eyr Ytterholmen
}

Dette er én av tre identiske ambulansebåter som betjener Helgelandskysten og som alle har navn fra
den norrøne gudinnen for legekunsten. Eyr Ytterholmen har hjemmehavn i Sandnessjøen og et mannskap
på to. 